\title{
PERANCANGAN FASILITAS DISPLAY MAKET FURNITUR MENGGUNAKAN MATERIAL BEKAS BANGUNAN DAN FURNITUR KAMPUS Studi Kasus: Service Learning Mata Kuliah Eko Desain 2017
}

\author{
Monica Santoso $^{1}$, Christine Yulie Kurrniawan ${ }^{1}$, Yusita Kusumarini ${ }^{1^{*}}$ \\ ${ }^{1}$ Program Studi Desain Interior, Fakultas Seni dan Desain, Universitas Kristen Petra \\ Jl. Siwalankerto 121-131, Surabaya 60236 \\ *Penulis korespondensi; email: yusita@peter.petra.ac.id
}

\begin{abstract}
Abstrak: Mata kuliah Eko-Desain 2017 di Program Studi Desain Interior meresponi permasalahan menumpuknya solid waste di kampus dengan metode service-learning untuk membantu memberikan alternatif solusi terhadap menumpuknya solid waste di institusi pendidikan Universitas Kristen Petra. Solid waste yang diresponi adalah menumpuknya furnitur bekas aktivitas kampus yang sudah habis masa pakainya, dan material bongkaran bangunan renovasi kampus yang telah menumpuk menjadi material bekas. Material bekas yang dipilih adalah kaca nako bekas jendela bangunan lama kampus dan besi bekas kursi kuliah. Prinsip eko-desain yang diterapkan adalah perancangan produk dari material bekas tersebut untuk menjadi produk fasilitas kampus kembali. Metode yang digunakan dalam proses perancangan produk adalah design thinking. Metode yang digunakan dalam proses pembelajaran adalah service-learning. Mitra dalam proses service-learning MK eko-Desain 2017 adalah civitas pengguna galeri pameran Program Studi Desain Interior, Unit Pelayanan dan Pemeliharaan Kampus, dan Wakil Rektor yang mengelola Sarana dan Prasarana Kampus. Perancangan ini menghasilkan tiga model produk display maket furnitur dengan gaya modernminimalis yang dapat juga digunakan di berbagai ruangan untuk fungsi lain-lain.
\end{abstract}

Kata kunci: Design thinking, service learning, display maket, material bekas.

\begin{abstract}
The 2017 Eco-Design course in the Interior Design Study Program responded to the problem of accumulating solid waste on campus with service-learning methods to help provide alternative solutions to the accumulation of solid waste in Petra Christian University educational institutions. Solid waste that was responded to was the accumulation of used furniture on campus activities that had expired, and the demolition material of campus renovation buildings that had piled up into used materials. The used material chosen is the nako glass used by the old campus building windows and used iron class chairs. The applied eco-design principle is the design of products from used materials to become a product of campus facilities again. The method used in the product design process is design thinking. The method used in the learning process is servicelearning. Partners in the 2017 Eco-Design course service-learning process are civitas users of the exhibition gallery of Interior Design Study Program, Campus Service and Maintenance Unit, and Vice Rector who manage Campus Facilities and Infrastructure. This design produces three models of furniture maket display products with a modern-minimalist style that can also be used in various rooms for other functions.
\end{abstract}

Keywords: Desing thinking, service learning, maquette display, waste material.

\section{PENDAHULUAN}

Fenomena menumpuknya material bekas di institusi pendidikan mulai sering ditemukan. Hal ini dapat dilihat dari banyaknya barang bekas atau sampah yang dijumpai disekitar lingkungan pendidikan. Sampah selain mencemari lingkungan juga mengurangi keindahan lingkungan [1]. Lingkungan pendidikan sendiri sangat luas sehingga terdapat banyak pengguna. Hal tersebut berdampak pada jumlah perabot, umur atau siklus pergantian penggunaan perabot yang semakin pendek, karena aktivitas dan perilaku pengguna yang beragam. Fenomena ini menyebabkan banyak barang 
bekas atau sampah disekitar lingkungan pendidikan, mulai dari perabot bekas /rusak seperti meja, kursi, tong sampah, rak sampai lemari.

Universitas Kristen Petra sendiri memiliki banyak material bekas yang disimpan di UPPK. Material tersebut antara lain kursi dengan material besi, kotak obat, lemari kayu, kaca nako bekas, dan lain-lain. Diantara material bekas yang ada, kursi besi dan kaca merupakan barang bekas paling banyak sehingga menumpuk dan memakan banyak tempat. Hal itu disebabkan karena limbah besi dan kaca merupakan bahan anorganik yang susah diolah dan tidak bisa terurai oleh alam.

Setiap semester mahasiswa seni dan desain dituntut untuk membuat suatu karya. Salah satunya adalah mahasiswa Desain Interior yang tiap semesternya diwajibkan untuk membuat maket. Secara bahasa, maket merupakan sebuah demonstrasi yang bertujuan untuk meningkatkan tampilan umum atau sesuatu dari yang kita rencanakan [2]. Maket dibuat untuk mempresentasikan apa yang akan dirancang oleh mahasiswa di setiap akhir semester. Banyak sekali mahasiswa kreatif yang menghasilkan maket yang layak untuk di display dan dapat menjadi inspirasi bagi mahasiswa-mahasiswa lainnya dalam pembuatan desain. Namun, di Universitas Kristen Petra masih minim untuk fasilitas display dan penyimpanan karya untuk Prodi Desain Interior, sehingga terpaksa banyak maket yang harus dibuang karena keterbatasan tempat penyimpanan.

Dari permasalahan diatas, ditemukan peluang untuk mengurangi sampah anorganik dengan mengolah kembali barang-barang bekas tidak terpakai menjadi suatu produk baru sebagai fasilitas di Universitas Kristen Petra. Dengan memanfaatkan rangka kursi bekas dan sisa kaca yang tidak terpakai, akhirnya dihasilkan ide untuk membuat display maket untuk memfasilitasi Prodi Desain Interior Universitas Kristen Petra.

Dari latar belakang tersebut, masalah yang dapat dijabarkan sebagai berikut:

1. Bagaimana kreativitas ide perabot baru dari perabot pendidikan rusak dan material bongkaran bangunan kampus untuk Prodi Desain Interior?

2. Bagaimana evaluasi hasil realisasi perabot baru untuk fasilitas Prodi Desain Interior?

\section{METODE PELAKSANAAN}

Proses pembelajaran di kelas menggunakan metode Service Learning, dan dalam perancangan desain menggunakan metode Design Thinking.

Proses pembelajaran di kelas menggunakan metode Service Learning sebagai berikut: a. Tahapan Observasi

Tahapan observasi dilakukan dengan mewawancarai civitas fakultas Seni dan Desain dan menyebarkan kuisioner kebutuhan. Salain itu juga dengan melakukan survey material bekas atau sisa di UPPK Universitas Kristen Petra.

b. Tahapan Pendampingan

Tahapan pendampingan dilakukan dengan konsultasi alternatif desain dengan dosen pembimbing dan mempresentasikan desain untuk mendapatkan kritik dan saran dari dosen mata kuliah dan mahasiswa kelas eko-desain.

c. Tahapan Uji Coba

Tahap uji coba dilakukan untuk mendapatkan saran dari pengguna melalui hasil produk di pameran dan melakukan evaluasi terhadap produk.

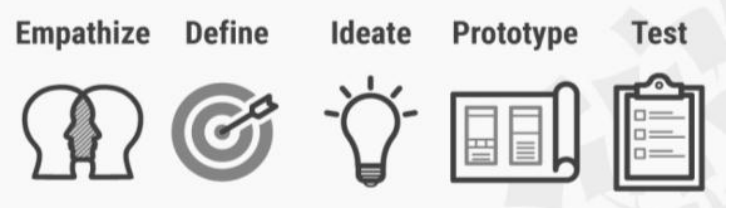

Gambar 1. Metode Design Thinking

Proses perancangan dengan metode design thinking dengan tahapan sebagai berikut:

d. Empathize

Empathize dilakukan untuk merasakan kebutuhan pengguna, dengan cara mencoba menempatkan diri sebagai pengguna sehingga dapat memahami kebutuhannya. Pada tahap ini, dilakukan survey untuk merasakan kebutuhan.

e. Define

Define dilakukan untuk mengetahui kebutuhan pengguna dengan cara menggambarkan pandangan pengguna yang akan menjadi dasar dari produk yang akan dibuat. Tahap ini dilakukan dengan cara melakukan survey dengan menyebarkan form identifikasi kebutuhan.Ideate

Ideate dilakukan untuk mengeluarkan ide untuk menjawab kebutuhan dan permasalahan yang ada. Pada tahap ini dilakukan diskusi dan brainstorming untuk memunculkan ide desain dari permasalahan yang ada. Setelah itu, membuat modeling beberapa alternative desain.

f. Prototype

Prototype dilakukan dengan cara mengimplementasikan ide dalam sebuah aplikasi atau produk uji coba. Tahap ini dilakukan dengan merealisasikan ide desain dengan membuat produk 1:1 dari setiap alternatif yang ada.

g. Test

Test dilakukan dengan cara uji coba produk, sehingga didapatkan masukkan untuk membuat produk yang lebih baik dan melakukan perbaikan pada produk yang ada. Tahap ini dilakukan untuk menguji prototype yang telah dibuat. 
Tabel 1. Metode Pelaksanaan

\begin{tabular}{|c|c|c|}
\hline Observasi & Pendampingan & Uji Coba \\
\hline $\begin{array}{l}\text { - Survey untuk merasakan kebutuhan } \\
\text { civitas Prodi Desain Interior } \\
\text { - Survey material bekas di UPPK Universitas } \\
\text { Kristen Petra } \\
\text { - Menyebarkan form identifikasi kebutuhan } \\
\text { fasilitas publik di kampus gedung P } \\
\text { Universitas Kristen Petra } \\
\end{array}$ & $\begin{array}{l}\text { - Mempresentasikan desain untuk mendapatkan } \\
\text { kritik dan saran dari dosen mata kuliah dan } \\
\text { mahasiswa kelas Eko Desain } \\
\text { - Konsultasi alternatif desain dengan dosen } \\
\text { pembimbing }\end{array}$ & $\begin{array}{l}\text { Evaluasi produk } \\
\text { dengan melakukan } \\
\text { wawancara dengan } \\
\text { pengguna }\end{array}$ \\
\hline Emphatize $\quad$ Define & Prototype & Test \\
\hline $\begin{array}{ll}\text { Menempatkan diri } & \text { Mengetahui kebutuhan } \\
\text { sebagai pengguna } & \text { pengguna dengan cara } \\
\text { dan memahami } & \text { menggambarkan } \\
\text { kebutuhannya } & \text { pandangan pengguna } \\
& \text { yang akan menjadi } \\
& \text { dasar dari produk yang } \\
& \text { akan dibuat } \\
& \text { - Melakukan peninjauan } \\
& \text { terhadap potensi } \\
& \text { penggunaan material } \\
& \text { bekas untuk } \\
& \text { pembuatan fasilitas } \\
& \text { umum } \\
\end{array}$ & $\begin{array}{ll}\text { Menjawab kebutuhan } & \text { Mengimplementasikan ide } \\
\text { dan permasalahan } & \text { dalam sebuah aplikasi atau } \\
\text { yang ada dengan } & \text { produk uji coba dengan } \\
\text { melakukan } & \text { merealisasikan desain skala } \\
\text { brainstorming untuk } & 1: 1 \\
\text { memunculkan } & \\
\text { alternatif ide desain } & \\
& \end{array}$ & $\begin{array}{l}\text { - Menguji prototype } \\
\text { yang telah dibuat } \\
\text { dengan } \\
\text { meletakkan } \\
\text { produk di gedung } \\
\mathrm{P} \\
\text { - Melakukan } \\
\text { evaluasi terhadap } \\
\text { produk }\end{array}$ \\
\hline
\end{tabular}

\section{PELAKSANAAN KEGIATAN}

\section{Tahapan Observasi}

Tahap ini menggunakan metode emphatize dan define dengan cara melakukan interaksi dengan pengguna, yaitu civitas Prodi Desain Interior untuk mengetahui kebutuhan dengan cara menyebarkan form kuisioner identifikasi kebutuhan fasilitas publik di kampus. Setelah penyebaran kuisioner, didapatkan bahwa salah satu kebutuhan terbesar adalah display maket, karena banyaknya maket berkualitas baik yang dapat menjadi inspirasi untuk orang lain yang terpaksa dibuang disebabkan kurangnya fasilitas penyimpanan.

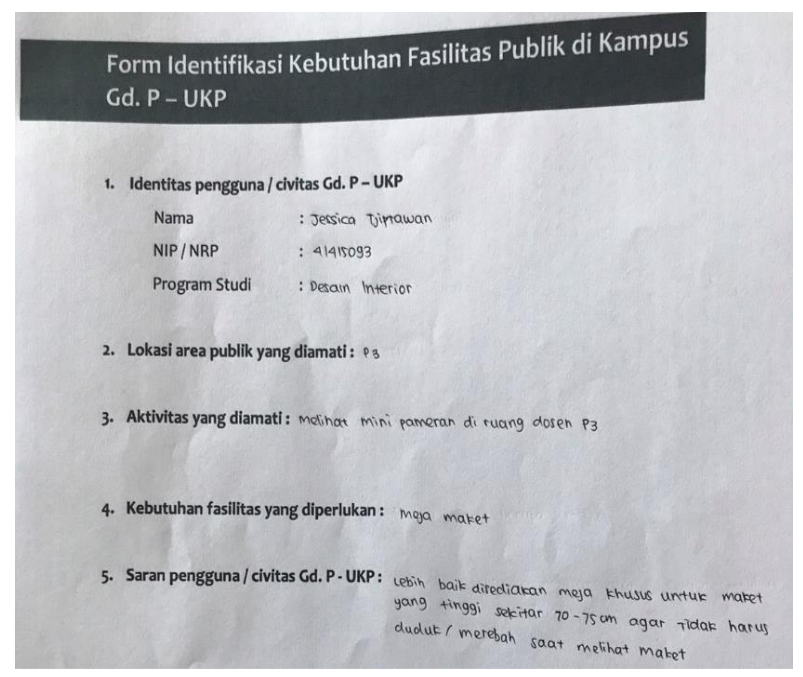

Gambar 2. Contoh Form Kuesioner

Setelah mengetahui kebutuhan civitas pengguna, dilakukan pemilihan material bekas yang berada di
UPPK. Setelah dilakukan survey mengenai material, dipilih material bekas kaca, karena merupakan salah satu material yang paling banyak menumpuk dan susah terurai dan juga kursi yang sudah tidak dapat digunakan lagi sudah menumpuk dan memakan banyak tempat.

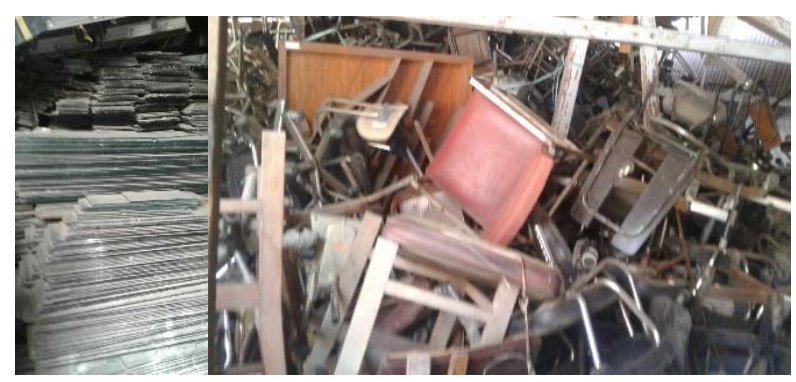

Gambar 3. Survey Material

\section{Tahapan Pendampingan}

Setelah melakukan identifikasi permasalahan dan memilih material, dilakukan tahap pendampingan dengan menggunakan metode Design Thinking ideate dan prototype. Tim bekerja sama mengkombinasikan material yang ada dan melakukan brainstorming untuk mendapatkan ide-ide desain. Setelah terbentuk beberapa alternatif desain, dilakukan konsultasi desain dengan dosen pembimbing dan juga dilakukan presentasi di kelas untuk mendapatkan kritik dan saran dari dosen mata kuliah dan mahasiswa di kelas sebagai salah satu civtias Prodi Desain Interior untuk pengembangan produk atau desain. Selanjutnya, desain akhir diproseskan untuk direalisasikan dengan bantuan dengan tenaga yang lebih ahli, yaitu tukang las besi. 


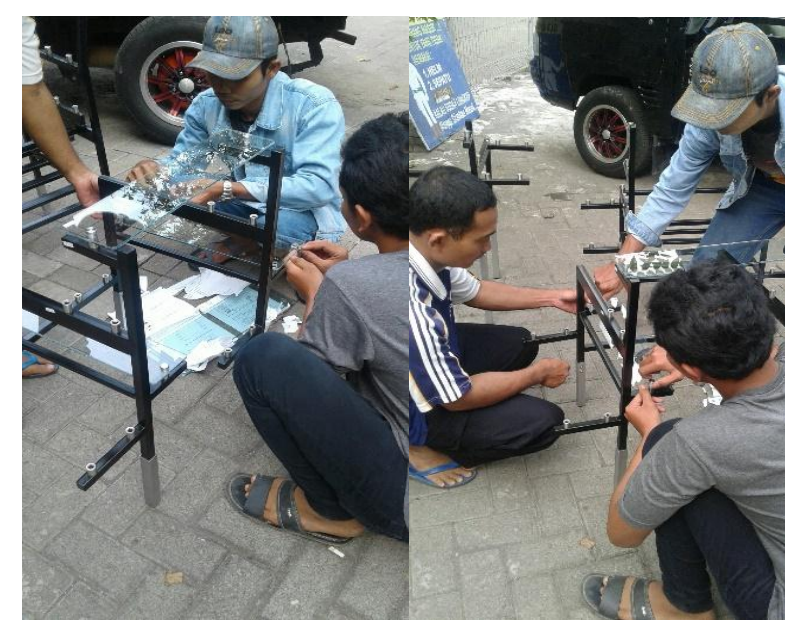

Gambar 4. Realisasi Desain

a. Ide Desain

Ide diperoleh dari kebutuhan civitas pengguna ruang galeri Prodi Desain Interior, ditemukan kebutuhan kurang atau minimnya tempat untuk menyimpan maket produk, karena banyak maket mahasiswa yang cukup baik dan bagus untuk di pamerkan, sekaligus menjadi inspirasi untuk orang lain. Oleh karena itu, dibutuhkan dan dibuat tempat maket/mockup untuk memenuhi kebutuhan tersebut.

b. Konsep Desain

Konsep produk adalah simple, modern-minimalis merupakan dasar ide konsep terbentuknya produk ini, karena era modern semakin berkembang, dan memudahkan semakin membantu untuk memenuhi kebutuhan manusia dengan pengunaan yang semakin mudah juga tidak rumit dan efisien.

c. Skematik Desain

Dalam perancangan produk, dibuat beberapa alternative bentuk agar pada saat produk ditata secara bersamaan tidak menimbulkan kesan monoton.
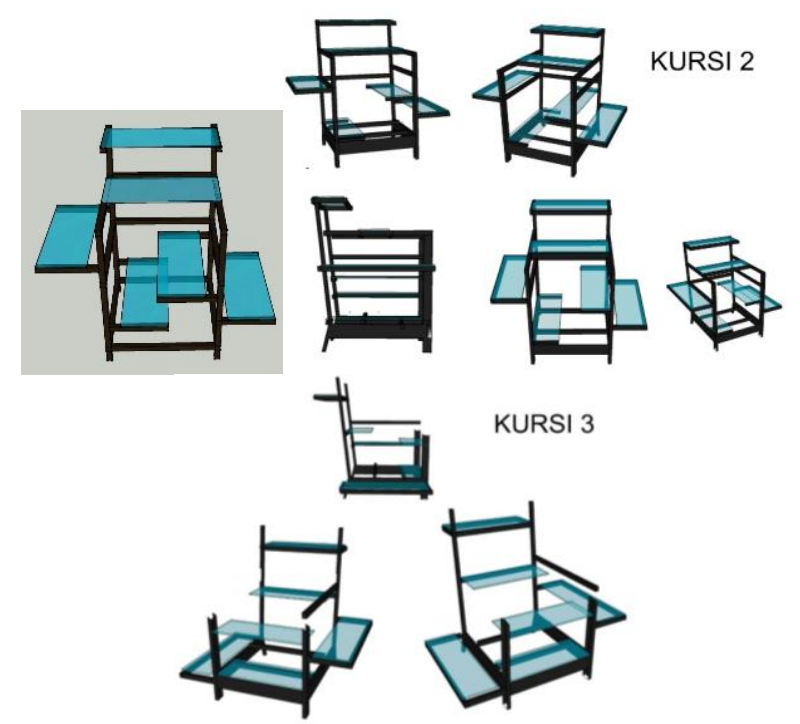

Gambar 5. Alternatif Desain d. Material

Material bekas ex. Perabot kampus yang digunakan adalah kursi dengan rangka besi dan kaca jendela nako bekas. Kursi yang diambil 6 buah, 3 diantaranya dibongkar sebagai bahan besi batang, dan 20 kaca nako bekas.

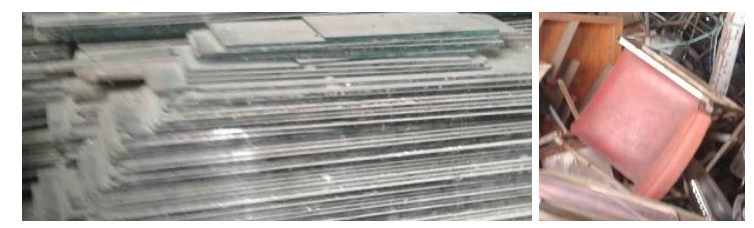

Gambar 6. Material Kaca dan Besi Bekas

e. Warna dan Finishing

Finishing besi menggunakan cat propan berwarna hitam.

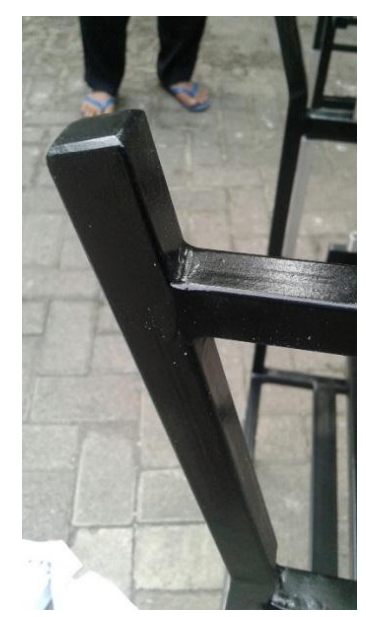

Gambar 7. Pelapis Besi

f. Proses Produksi

Setelah melakukan proses pemilihan material dan pembuatan desain, dilakukan proses produksi untuk membuat prototype. Berikut adalah beberapa tahapan dalam proses produksi.

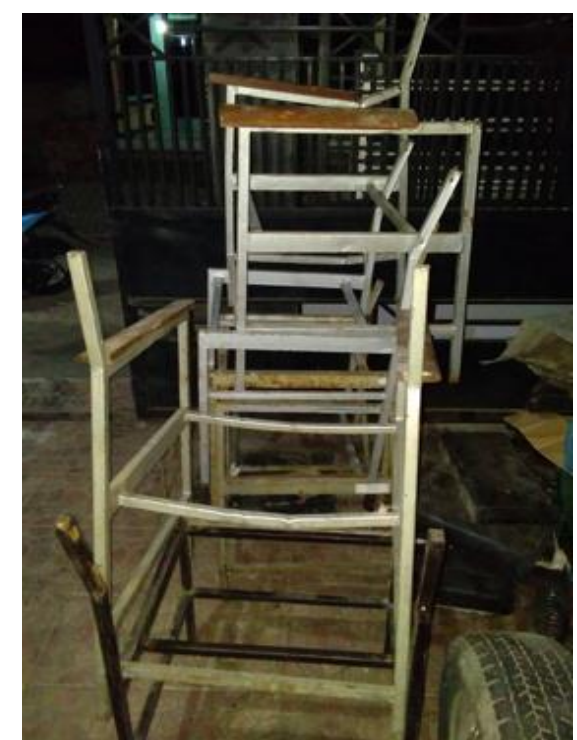

Gambar 8. Pengumpulan Material Bekas 


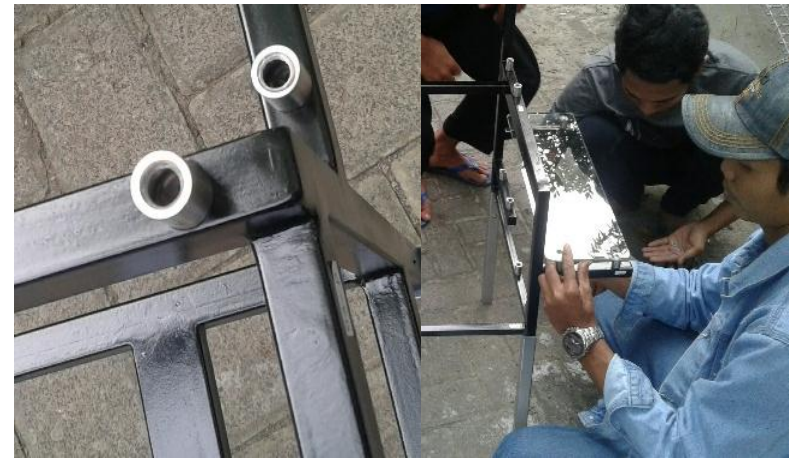

Gambar 9. Pemasangan Baut

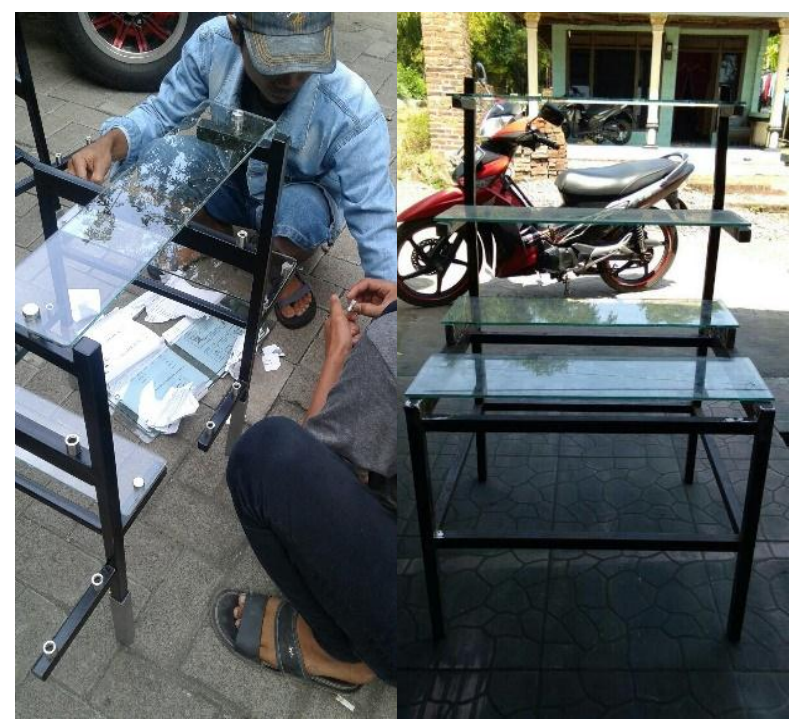

Gambar 10. Pemasangan Kaca

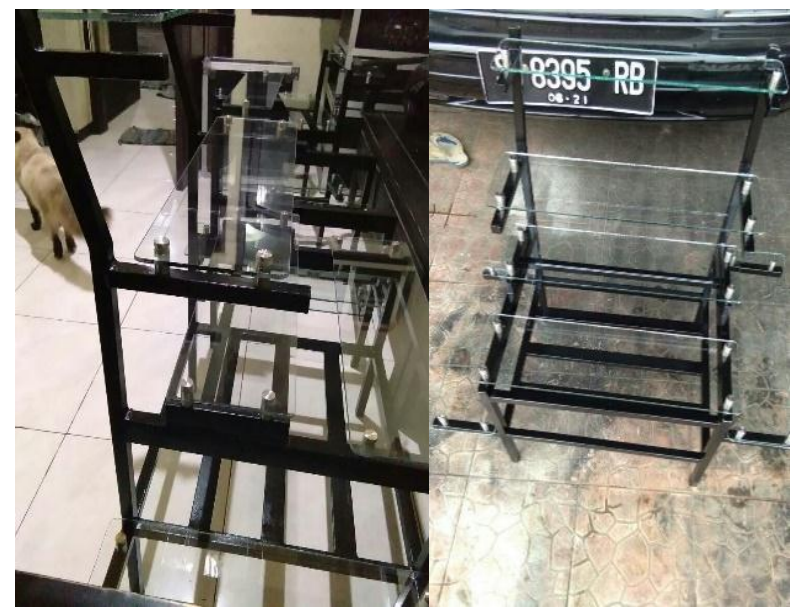

Gambar 11. Pelapis Akhir Produk

\section{g. Hasil Akhir Produk:}

1. Tempat untuk menyimpan atau mengumpulkan maket yang dapat juga dipamerkan untuk menjadi inspirasi bagi mahasiswa

2. Meletakkan maket produk pada bagian kaca.

3. Maket memiliki ketinggian yang mudah untuk dijangkau dan terbuat dari kaca transparan, sehingga mudah terlihat.

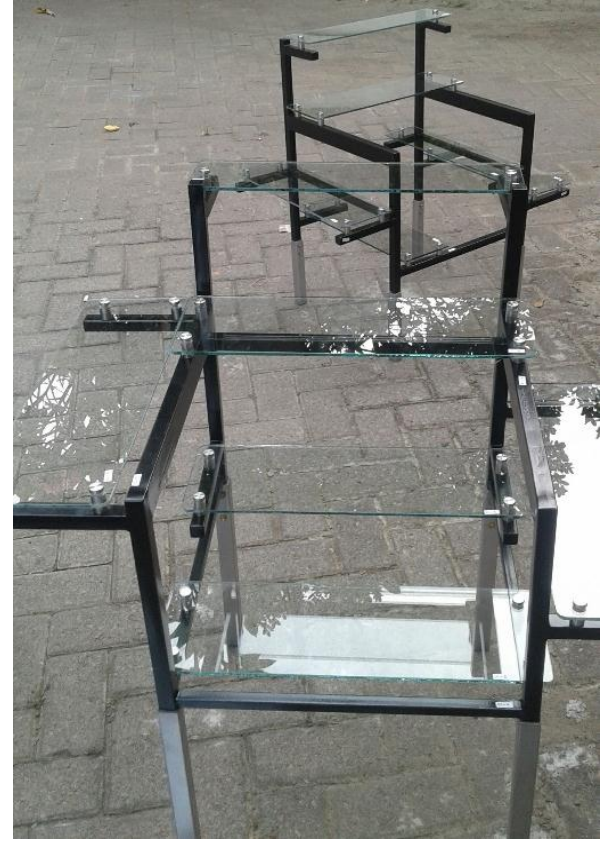

Gambar 12. Hasil Jadi Produk

\section{Tahapan Uji Coba}

Produk yang telah diproduksi diuji coba dengan dilakukan pameran dan meletakkan produk di gedung P lantai 1. Produk cukup mendapat respon prositif dari pengguna dan cukup menjawab permasalahan, karena dapat menjadi sarana inspirasi bagi pengguna dengan tampilan yang unik dan mudah dilihat. Produk juga mendapatkan penilaian dari UPPK dan WR2 serta terdapat refleksi mengenai kegiatan Service Learning yang dibuat oleh mitra, mahasiswa dan dosen.

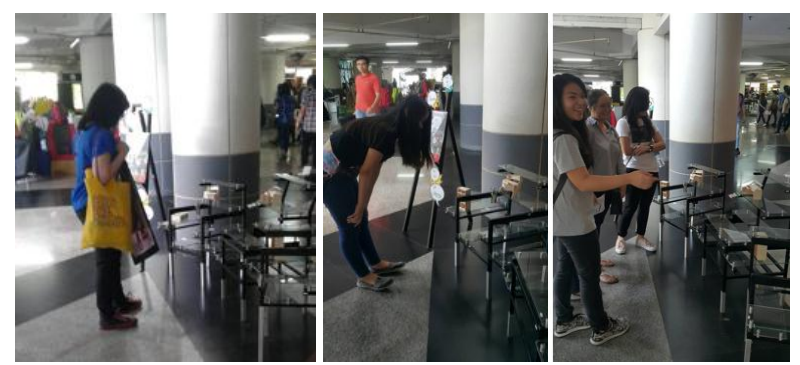

Gambar 13. Uji Coba Produk

\section{Evaluasi}

Melalui tahap uji coba, dapat dilakukan evaluasi terhadap produk baru yang telah dibuat. Berdasarkan pengamatan, produk ini telah dapat memenuhi kebutuhan akan fasilitas display untuk maket Prodi limbah di lingkungan Universitas Kristen Petra. Produk tersebut juga dapat digunakan untuk fungsi display sealin display maket furnitur di ruang lain sesuai dengan kebutuhan. Kekurangan pada produk ini, diatranta adalah sisi keamanan penggunaan dan kemudahan perawatan produk. 


\section{SIMPULAN}

Setelah pelaksanaan Mata Kuliah Eko-Desain 2017, berikut simpulan yang dapat dikemukakan:

1. Kreativitas ide perabot baru sesuai eksplorasi kebutuhan yang diresponi adalah display maket furnitur yang memanfaatkan material bekas, yaitu besi bekas dari perabot kursi dan kaca nako bekas jendela yang direnovasi.

2. Evaluasi hasil realisasi perabot baru untuk fasilitas Prodi Desain Interior, yaitu:

Kelebihan:

a. Memenuhi kebutuhan Prodi Desain Interior dalam bentuk penyimpanan dan display maket furnitur.

b. Ergonomis, karena mudah dijangkau dan juga mudah terlihat.

c. Bentuk bervariasi, sehingga pada saat digabungkan tidak terlihat monotone.

d. Mengurangi limbah di lingkungan universitas dengan mengolahnya menjadi perabot baru dengan bentuk yang eksklusif.
Kekurangan:

a. Alas bermaterial kaca, sehingga rawan pecah terutama jika ditempatkan di tempat umum

b. Terbuka yang menyebabkan mudah kotor dan berdebu, sehingga pembersihan rutin.

\section{DAFTAR PUSTAKA}

Huda, N, dan Dewi, Novi Ratna. (2012). Pemanfaatan Kertas Bekas Bungkus Rokok Untuk Meningkatkan Keaktifan Siswa Dalam Membuat Rangkaian Listrik 3 In 1. Unnes Science Education Journal, Vol. 1, No. 1: 44-49.

Khairi, Zaimmudin. (2012). Efektivitas Media Maket Sebagai Representasi Karya Perancangan Arsitektur di Era Digital. FT UI.

https://www.interaction-design.org/literature/topics/ design-thinking. 